\title{
Geomorphological signature and flow dynamics of The Minch palaeo-ice stream, NW Scotland
}

\author{
Tom Bradwell*1, Martyn Stoker ${ }^{1} \&$ Rob Larter ${ }^{2}$ \\ ${ }^{1}$ British Geological Survey, Murchison House, West Mains Road, Edinburgh, EH9 3LA, UK \\ ${ }^{2}$ British Antarctic Survey, High Cross, Madingley Road, Cambridge, CB3 OET, UK \\ *corresponding author: email: tbrad@bgs.ac.uk phone: 01316500284 fax:01316681535
}

\begin{abstract}
Large-scale streamlined glacial landforms are identified in 11 areas of NW Scotland, from the Isle of Skye in the south to the Butt of Lewis in the north. These ice-directional features occur in bedrock and superficial deposits, generally below $350 \mathrm{~m}$ above sea level, and where best developed have elongation ratios of $>20: 1$. Sidescan sonar and multibeam echo-sounding data from The Minch show elongate streamlined ridges and grooves on the seabed, with elongation ratios of up to 70:1. These bedforms are interpreted as mega-scale glacial lineations. All the features identified formed beneath The Minch palaeo-ice stream which was c. $200 \mathrm{~km}$ long, up to $50 \mathrm{~km}$ wide and drained $\sim 15,000 \mathrm{~km}^{2}$ of the NW sector of the last British-Irish Ice Sheet (Late Devensian Glaciation). Nine ice-stream tributaries and palaeoonset zones are also identified, on the basis of geomorphological evidence. The spatial distribution and pattern of streamlined bedforms around The Minch has enabled the catchment, flow paths and basal shear stresses of the palaeo-ice stream and its tributaries to be tentatively reconstructed.
\end{abstract}

Keywords: British-Irish Ice Sheet, Late Devensian, subglacial bedforms, palaeo-glaciology

\section{Introduction}

The palaeo-glaciology of the British-Irish Ice Sheet remains poorly understood despite a long history of glacial research in the UK. Renewed interest in the former dynamics of this ice sheet has been prompted by several factors, namely: - the recognition of palaeo-ice streams in the geological record (eg. Stokes \& Clark, 1999; 2001a); the publication of the BRITICE map and GIS (Clark et al, 2004); and the advent of new, high-resolution, remotely sensed datasets and improved interpretation software (eg. Jansson \& Glasser, 2005; Everest et al., 2006a; Golledge \& Stoker, 2006). The identification of palaeo-ice streams - fast-flowing zones responsible for discharging most of the ice - within the last British-Irish Ice Sheet is crucial to 
understanding the former dynamics, flow paths and stability of the whole ice mass (eg. Boulton \& Clark, 1990; Paterson, 1994; Stokes \& Clark, 2001a). Moreover, ice streams are capable of rapidly discharging large volumes of fresh water into the ocean - a potentially key forcing mechanism of abrupt climate change (e.g. Heinrich, 1988; Broecker, 2003; Alley et al., 2003).

In this paper we identify streamlined subglacial landforms on land and on the seabed in NW Scotland associated with a large palaeo-ice stream that drained c. $15,000 \mathrm{~km}^{2}$ of the NW sector of the British-Irish Ice Sheet several times during the mid to late Pleistocene (Stoker and Bradwell, 2005). We suggest that The Minch palaeo-ice stream would have dominated the configuration of the NW sector of the last British-Irish Ice Sheet (Late Devensian; Marine Isotope Stage 2), and probably influenced the ice-divide location and the ice-sheet thickness across the whole region.

The quality and density of glacial geomorphological mapping in Britain vary significantly, as highlighted by the BRITICE database (Clark et al., 2004) and the accompanying literature review (Evans et al., 2005). Although NW Scotland has long been a focus for geological investigation (e.g. Lapworth, 1886; Peach et al., 1907), comparatively little Quaternary science has been carried out in the region (eg. Peach \& Horne, 1892; Read et al., 1926). Much of the glacial history of the NW Highlands derives from work undertaken since 1980 by Lawson (eg. 1986, 1990) and Ballantyne and co-workers $(1990,1994,1995,1998)$. The work of the latter attempts to reconstruct the surface altitude of the last ice sheet based on high-level glacial 'trimlines' and periglacial phenomena. Palaeo-nunataks have been identified on this basis throughout NW Scotland (Ballantyne et al., 1998). However, distinguishing between ice-free areas and those that were covered by cold-based non-erosive ice is a complex issue (eg. Kleman and Stroeven, 1997; Fabel et al., 2002).

The island of Lewis has received attention from only a handful of glacial geologists. Since John Geikie in 1873, only von Weymarn (1979), Flinn (1978), Sissons (1980), Peacock (1984) and Ballantyne \& McCarroll (1995) have tried to unravel the complex glacial history of Scotland's largest island. Recently, Stone \& Ballantyne (2006) revised their earlier regional model (ie. Ballantyne et al., 1998) presenting a dated reconstruction of the Outer Hebrides ice cap at Last Glacial Maximum (LGM). However, the glaciation of the Outer Hebrides is much debated. Until the 1970s it was commonly presumed that the last BritishIrish ice sheet crossed Lewis in a westerly direction from its main source area on the Scottish Mainland (eg. Geikie, 1873; Jehu and Craig, 1934; Sissons, 1967). This view was challenged by von Weymarn $(1974,1979)$ and Flinn $(1978)$ who proposed, based on geomorphological 
evidence, that the Outer Hebrides had supported an independent ice cap during the LGM. This view was reinforced by Peacock $(1984,1991)$ based on British Geological Survey (BGS) field mapping in Lewis, Harris and South Uist. Reconstructed maximum ice-sheet altitudes are also consistent with ice from the Outer Hebrides merging with Scottish mainland ice in The Minch (Ballantyne, 1990; Ballantyne et al., 1998). Although the concept of an independent ice dome over the Outer Hebrides is now widely accepted, controversy regarding the lateral and vertical extent of the ice sheet in NW Scotland remains (Figure 1) (eg. Sutherland, 1984; Stoker et al., 1993; Bowen et al., 2002; Hall et al., 2003; Stone \& Ballantyne, 2006).

\section{Method and Results:}

NEXTMap digital surface models, aerial photographs and field mapping were used to interpret the onshore geomorphology in parts of NW Scotland. The marine landscape was examined using UDI AS350 dual sidescan-sonar imagery $(50 \mathrm{kHz})$, collected by the BGS in 1984 as part of their regional mapping programme of the UK continental shelf, in combination with Kongsberg-Simrad EM120 multibeam swath bathymetry data (12 kHz; 191 beams; $1^{\circ} \times 1^{\circ}$ beam width; $10 \mathrm{~m}$ grid spacing in image), acquired by the British Antarctic Survey in 2005 onboard RRS James Clark Ross. The integration of new and legacy datasets allows high-resolution imagery of palaeo-ice stream bedforms in Britain, both onshore and offshore, to be presented here for the first time. Several key locations have been identified on land in NW Scotland, surrounding The Minch (Figure 2:A-L), along with one on the seabed (Figure 2:M \& Figure 3). These are described in turn. (All places referred to are shown in Figure 1.)

A. Streamlined landforms occur in bedrock and glacial deposits around the western shore of Broad Bay, NE of Stornoway (Figure 2A). The features are best developed in the Permo-Triassic sandstones around Vatisker Point where they are up to $1.5 \mathrm{~km}$ long. The landforms are chiefly low-relief drumlins with elongation (length:width) ratios of 3 or 4:1. The overall flow set is weakly convergent, suggesting palaeo-ice flow from Lewis towards The Minch in an easterly direction. Large meltwater channels occur between the drumlins in places.

B. Elongate streamlined landforms on Lewisian gneiss bedrock occur immediately west of Stornoway (Figure 2B). These features are chiefly large-scale crag and tails, bedrock-cored megaflutes and megadrumlins typically 1-2 km in length. Elongation ratios range from 3:1 to 8:1. The flow set is weakly convergent towards Stornoway, suggesting palaeo-ice flow in an easterly direction in this part of Lewis. This flow orientation is consistent with glacial striae and till fabric data reported by Peacock 
(1984). Rock drumlins, whalebacks and large-scale bedrock grooves $(<0.5 \mathrm{~km}$ long $)$ occur around Loch Orasay.

C. Strongly streamlined Lewisian gneiss landscape occurs around Loch Erisort, eastern Lewis (Figure 2C). Elongate large-scale crag and tails, bedrock-cored megadrumlins and streamlined bedrock hills with long axes up to $1 \mathrm{~km}$ trend slightly north of east. Elongation ratios range from $3: 1$ to $6: 1$. Ice flow in this area was along the axis of Loch Erisort towards The Minch, as shown by striae and small ice-moulded forms (Peacock, 1984).

D. Large-scale streamlined bedrock forms occupy the ground between the Trotternish and Vaternish peninsulas on the Isle of Skye (Figure 2D). These subtle features include rock drumlins, fluted bedrock and large-scale grooves - all cut into basaltic bedrock. The largest rock drumlin is $1.2 \mathrm{~km}$ long with an elongation ratio of 5:1. Ice flow during the Main Late Devensian glaciation was in a NNW'erly direction along the axis of Loch Snizort as supported by glacial striae on the shore of the loch (Johnstone \& Mykura, 1989).

E. Highly abraded, streamlined bedrock forms occupy the low ground between Ben Stack and Arkle in NW Scotland (Figure 2E). The primary features are large-scale whalebacks, and streamlined hills of Lewisian gneiss and metagranite up to $1 \mathrm{~km}$ in length. BGS field mapping has shown that these features are ornamented with smaller whalebacks and other ice-moulded forms on an outcrop scale ( $\sim 5-50 \mathrm{~m}$ long). Megagrooves, up to $30 \mathrm{~m}$ deep, dissect the terrain along structural weaknesses. Icesheet flow was WNW towards The Minch, and was probably fastest flowing in the topographic trough occupied by Loch Laxford.

F. Raasay is a narrow north-south aligned island adjacent to Skye with overdeepened rock basins to the east and west. The northern half of the island is scoured Lewisian gneiss bedrock. Ice-moulded forms, rock drumlins and large-scale grooves are well developed, particularly around Manish Point (Figure 2F). The rock drumlins range in size from 50 to $500 \mathrm{~m}$ in length with elongation ratios typically c. $3: 1$. The rock-cut grooves and channels are persistent over distances of 1000-2000 m. All these bedrock features are orientated north-south, consistent with palaeo-ice flow from the mountains of Skye towards The Minch and supported by glacial striae on northern Raasay (Johnstone \& Mykura, 1989).

G. Drumlins occur on the Isle of Ewe in both bedrock and glacial deposits (Figure 2G). The southern half of the island has a streamlined till surface whilst the northern half has little glacial sediment cover. Many of the larger drumlins are erosional bedrock features with long axes typically $\sim 0.5 \mathrm{~km}$ and elongation ratios of $>3: 1$. The trend of 
the streamlined landforms, combined with striae data (Johnstone \& Mykura, 1989), suggest palaeo-ice flow in a NW'erly direction into The Minch.

H. Fluted bedrock and large-scale, closely spaced, grooves occur on the ground $\sim 5 \mathrm{~km}$ SW of Loch Glencoul in Assynt (Figure 2H). The Moine Supergroup psammite bedrock shows clear evidence of strong glacial abrasion in the form of striae, whalebacks and other small-scale ice-moulded forms (BGS field survey). The features are all orientated NW and only occur in the wide topographic depression between Ben More Assynt and Ben Leoid. The streamlined landforms and glacial striae (Geological Survey of Great Britain, 1923) testify to palaeo-ice flow in a NW'erly direction into the Glencoul trough and towards The Minch.

J. Stongly parallel megagrooves in Cambrian quartzite and Neoproterozoic sandstone bedrock trend WNW near Cam Loch, in Assynt (Bradwell, 2005) (Figure 2J). These mega-scale glacial lineations are not structurally controlled and cross major lithological boundaries. The megagrooves range in length from 500-4300 $\mathrm{m}$ and are generally 20-30 m wide. Spacings vary from 20 to $200 \mathrm{~m}$. Palaeo-ice sheet flow in this area was to the NNW, parallel to the megagrooves, as evidenced by abundant glacial erratics, striae, and ice-moulded bedrock forms (Johnstone \& Mykura, 1989; Lawson, 1990).

K. Mega-scale glacial lineations (MSGL) occur in bedrock on the watershed in Rhidorroch, to the NE of Ullapool (Figure 2K). These closely spaced, strongly parallel, features cut into hard Proterozoic Moine Supergroup psammites range from 500 to $5000 \mathrm{~m}$ in length and are orientated east-west. The primary landforms are erosional megagrooves ranging from 10 to $50 \mathrm{~m}$ wide with average spacings of 100$200 \mathrm{~m}$. The intervening bedrock ridges are highly elongate and drumlinoid in form akin to megaflutes. The longest ridges have elongation ratios of 15-25:1. Palaeo-ice flow in Rhidorroch was from east to west, as deduced by the transport of glacial erratics and striae orientations (Read et al., 1926).

L. MSGL in superficial deposits, chiefly till and morainic diamict, occur to the $\mathrm{N}$ of Beinn a' Chlachainn on the Applecross pensinula (Figure 2L). These highly elongate streamlined ridges and grooves cover an area of $\sim 20 \mathrm{~km}^{2}$ and trend northwards. The ridges range in length from 2 to $4.5 \mathrm{~km}$ and have elongation ratios of up to 20:1. The whole flow set is strongly convergent from south to north suggesting palaeo-ice flow from the mountains of Applecross towards The Minch. These glacially streamlined deposits are superimposed on glacially striated and grooved Torridonian sandstone bedrock possessing the same feature orientation (Johnstone \& Mykura, 1989).

M. In The Minch, swath bathymetry and sidescan-sonar images reveal large-scale ridgegroove structures on the sea floor between the NW Scottish mainland and Lewis 
(Figure 3). These strongly parallel, highly elongate features are developed in diamicton, as indicated by sub-bottom profiles and borehole data, and have been interpreted as MSGL (Stoker \& Bradwell, 2005). The sidescan-sonar images show that the lineations are of high density, and are expressed by a hummocky or corrugated sea floor with a relief of 5-15 m, and ridge spacing of c. 100-500 m

(Figure 3). Stoker \& Bradwell (2005) reported a minimum elongation ratio of 7.5:1, derived from the limited horizontal range of the sidescan image, but inferred the likelihood of much greater ratios on the basis of the widespread distribution of these features on the sea bed. This is confirmed by the newly acquired multibeam data, which indicates that individual lineations can be traced for thousands of metres (up to $7000 \mathrm{~m}$ within the confines of the dataset) indicating elongation ratios up to 70:1. Significantly, perhaps, the multibeam data reveal two separate lineation trends, N-S (mean bearing $=350)$ and NNW-SSE (mean bearing $=338$ ); the latter being most dominant within the area of acquisition, and appearing to cross-cut the former.

\section{Discussion}

Stoker \& Bradwell (2005) identified a major palaeo-ice stream draining the NW sector of the last British-Irish ice sheet based on a combination of legacy geophysical (seismic profiles and sidescan sonar) data and recent geological mapping. New work, presented here, combines legacy data with the recently acquired NEXTMap digital surface models of the land, and new multibeam swath data of the seabed, to more accurately determine the spatial extent and flow paths of The Minch palaeo-ice stream and illustrate its geomorphological signature. The evidence of ice streaming is seen most clearly and unequivocally on the coastal fringes of NW Scotland, around Loch Broom (Rhidorroch), in Assynt, in Applecross and in eastern Lewis (Figure 2: B, J, K, L). In these localities mega-scale highly streamlined bedforms occur with elongation ratios $>7: 1$, and locally in excess of 20:1. MSGL in unlithified deposits are thought to form by subglacial deformation and attenuation of the underlying soft sediments, or groove ploughing by the ice-sheet bed (eg. Hindmarsh, 1998; Clark et al., 2003). However, the exact formation mechanism of MSGL in bedrock remains elusive. Focused glacial abrasion and high-energy subglacial meltwater are both likely to play key roles in megagroove formation (Smith, 1948; Boulton, 1979; Bradwell, 2005). Other localities with less pronounced streamlined bedforms (elongation ratios $<6: 1$ ) indicate the onset of ice streaming - in NE Lewis, on Raasay, in Loch Ewe, around Loch Snizort (Skye), and around Loch Laxford (Figure 2: A, D, E, F, G). 
The presence of glacial lineations on the seabed could be interpreted as either glacial sole markings or iceberg plough marks. Based on the strong preferred orientation of the lineations (N-S and NNW-SSE), their scale (100-500 m wide; 1-7 km long), morphology (long, linear features, rather than irregular, wandering tracks) and strong parallelism, they are interpreted as MSGLs that formed at the base of a grounded ice stream. Furthermore, iceberg plough marks normally vary in width and depth where the keels of bergs rotate or carve erosional pits. The ridge and groove morphology seen in the multibeam image (Figure 3) show very little width or depth variation and are similar to MSGLs identified in other palaeo-ice stream tracks in Hudson Bay, Canada (Josenhans, 1997), offshore Norway (Sejrup et al., 2003; Stalsberg et al., 2003; Ottesen et al., 2005) and Antarctica (Pudsey et al., 1994; Ó Cofaigh et al., 2002; Dowdeswell et al., 2004).

The new geomorphological evidence (Figures $2 \& 3$ ) has been used to reconstruct the flow paths of The Minch palaeo-ice stream at its maximum extent (Figure 4). Examination of the regional pattern across the study area shows a large convergent flow set in The Minch, as outlined by Stoker \& Bradwell (2005). In more detail, we have identified individual onset zones that delimit 'tributaries' feeding The Minch ice stream (Figure 4). Palaeo-ice-stream tributaries have been identified in several topographic troughs in NW Scotland: off Raasay; in Loch Ewe; outer Loch Broom; Enard Bay; Edrachillis Bay; Loch Laxford; possibly Loch Snizort on Skye; and in eastern Lewis, along Broad Bay and Loch Erisort. Therefore, The Minch palaeo-ice stream was fed by at least 9 ice-stream tributaries draining primary onset zones. These tributaries coalesced in the northern Minch to flow as a large coherent palaeoice stream on the continental shelf (Figure 4). We suggest that these tributaries represent the zones of transition from slow flowing, cold-based, inland ice to fast-flowing, warm based, streaming ice. Similar ice-stream feeders have been shown to mark a flow transition within the Antarctic ice sheet (Bamber et al., 2000; Vaughan et al., 2006).

Although comprising a component of ice flow from the Outer Hebrides, the ice stream was dominated by ice streaming west and north from the NW Scottish Highlands and Skye. This is consistent with the two cross-cutting sets of MSGL observed on the sea bed, indicating that ice flow from the Scottish mainland dominated the trunk of the ice stream. It is possible that the earlier flow set represents an ice stream that was predominantly fed by ice sourced to the south on Skye and around Loch Carron; whilst the later set represents an ice stream predominantly sourced to the SE in the mountains of Wester Ross and Assynt. Consequently, the cross-cutting MSGL may relate to shifts in dominance of the palaeo-icestream source and concomitant adjustments of the main ice-stream flow path during ice-sheet growth and decay. Studies in West Antarctica have shown that fluctuations in ice stream size 
and vigour can result in a regionally lowered ice-sheet surface, ice piracy and the migration of ice divides (Alley \& Whillans, 1991; Truffer \& Echelmeyer, 2003). It is reasonable to assume that The Minch palaeo-ice stream probably influenced the ice-divide location and ice-sheet thickness across the NW sector of the last British-Irish ice sheet. Prolonged ice stream growth would have increased ice downdraw within the fjords of NW Scotland, consequently forcing the ice-sheet divide on the mainland to migrate eastwards over time.

Shelly tills, Torridonian sandstone erratics and glacial deposits indicating anomalous ice-flow directions have been reported from northernmost Lewis (Peacock, 1984). Tills of glacimarine origin, based chiefly on the presence of marine shells, are reported at Tolsta Head, Port of Ness and on the Butt of Lewis (Baden-Powell, 1938; von Weymarn, 1974; Peacock, 1984). Moreover, the presence of Torridonian erratics on the Eye Peninsula, Tolsta Head and the Butt of Lewis has long been held as evidence of glaciation by ice from the Scottish Mainland (Geikie, 1873; Peacock, 1984). In the light of our new findings, we find this compelling supporting evidence for the presence of a large palaeo-ice stream in the Minch, the southern margin of which overrode the northernmost part of Lewis. Other anomalous field evidence in Lewis could be reconciled if this new ice-sheet flow model is adopted. For example, the identification of a large linear morainic ridge (Peacock, 1984) in northernmost Lewis could now be interpreted as a possible ice-stream shear-margin moraine (cf. Stokes \& Clark, 2001b).

Seismic profiles show the sedimentary architecture of the Outer Hebrides Shelf to comprise a complex stacked sequence of diamictons and layered proglacial sediments that terminate in the Sula Sgeir trough mouth fan on the adjacent slope (Stoker et al., 1993). Shelf-wide glaciation, with ice streams terminating at the shelf-edge, has affected this part of the continental margin on several occasions in the last 0.5 Ma (Stoker 1995). However, the westward extent of the Late Devensian British-Irish ice sheet is still uncertain, though sea bed MSGLs are seen on the Hebrides Shelf (Stoker \& Bradwell, 2005). The presence of undisturbed glacimarine deposits of Early Devensian age (MIS 4) on the outer shelf (Stoker et al., 1993) places the grounded Late Devensian ice-sheet limit on the mid shelf (Stoker \& Bradwell, 2005). Therefore, we hypothesise that at Last Glacial Maximum, The Minch ice stream terminated on the continental shelf, NW of Lewis, probably in the vicinity of Sula Sgeir. However, the possibility that the ice sheet extended towards the continental-shelf break as a floating ice shelf cannot be ruled out (Figure 4).

Present-day ice streams are characterized by low surface slopes, low driving stresses and rapid velocities (Alley and Whillans, 1991). Low shear stresses often indicate the presence of 
deformable subglacial sediments, but may also reflect rapid basal sliding as a result of abundant subglacial meltwater (e.g. Kamb, 1991; Paterson, 1994).

Our reconstruction of the Minch palaeo-ice stream can be used to calculate the upper limit of basal shear stress $\left(\tau_{\mathrm{b}}\right)$ conditions within the downstream section of the ice stream, using the equation:

$$
\tau_{\mathrm{b}}=\rho g h \tan \alpha \quad(\text { Hooke, 2005) }
$$

Where $\rho=$ ice density $\left(900 \mathrm{~kg} \mathrm{~m}^{-3}\right), \mathrm{g}=$ gravitational acceleration $\left(9.8 \mathrm{~m} \mathrm{~s}^{-2}\right), \mathrm{h}=$ ice thickness (m) and $\alpha=$ ice-sheet surface slope $\left({ }^{\circ}\right)$. Assuming that Ballantyne et al. (1998) have correctly identified the maximum ice-sheet altitude at $\sim 800 \mathrm{~m}$ on The Cuillin mountains, Isle of Skye, we then assume an altitude of $150 \mathrm{~m}$ below present-day sea level for the grounding line, near Sula Sgeir, $210 \mathrm{~km}$ away. These values yield an average surface slope of $0.26^{\circ}$ for the ice sheet along a palaeo-flow line. It is not realistic to assume a constant gradient along the length of the ice stream, however the gradient of the trunk of the ice stream would have been lower than the average gradient over its entire length (ie. $<0.26^{\circ}$ ) as shown by modern analogues (Alley and Whillans, 1991; Truffer and Echelmeyer, 2003). Taking an icesheet thickness of $500 \mathrm{~m}$ - the minimum value on the northern tip of Skye, according to Ballantyne et al's (1998) reconstruction - yields a basal shear stress value of $20 \mathrm{kPa}$. It follows that the gradient of the trunk of the ice stream in The Minch and, hence, the basal shear stress must be lower than this figure. Therefore the value of $20 \mathrm{kPa}$ can be regarded as a maximum approximation for basal shear stress values within the trunk of The Minch palaeoice stream. It is interesting to note that this is considerably lower than the values derived by Ballantyne et al. (1998) for the same sector of the British-Irish ice sheet where no ice stream was invoked (cf. 55-77 kPa). By way of comparison, basal shear stress values for many modern Antarctic ice streams are found to be in the region of 3-20 kPa (Alley 1993; Truffer \& Echelmeyer, 2003). Our preliminary calculations of ice-stream flow dynamics would tend to support the lateral extent, approximate ice thickness and flow model proposed for the NW sector of the last British-Irish ice sheet.

Presently, no firm dates can be given for the precise timing of ice stream operation in NW Scotland. Cosmogenic-nuclide exposure dating of an ice-sheet moraine in Gairloch, Wester Ross, has yielded an age of c.16-17 ka BP (Everest et al., 2006b). Whilst recently acquired cosmogenic dates from the east coast of Harris also yield similar exposure ages (15.4-17.6 ka BP; Stone \& Ballantyne, 2006). These data, combined with marine fauna from borehole 78/4 off Stornoway (Graham et al., 1990) (Figure 1), provide minimum ages for deglaciation of The Minch. Consequently, it is likely that the ice stream last operated from glacial maximum c.22-25 ka BP until c.17 ka BP. The exact mechanisms and causes of ice-stream demise and 
subsequent ice-sheet disintegration are unclear. However, retreat of the NW sector of the last British-Irish ice sheet would have been intimately associated with sea-level rise. Accelerated eustatic sea-level rise c.19 ka BP (P.U.Clark et al., 2004) may have triggered rapid retreat, or collapse, of the ice sheet's Atlantic margins. It is possible that The Minch ice stream disintegrated soon after this eustatic event, probably around the time of Heinrich event 1 (c.17-18 ka BP; Bond et al., 1992). By 15 ka BP arctic open-water conditions existed in The Minch (Graham et al., 1990), when the ice-sheet margin was situated at, or close to, the present-day coastline in NW Scotland (Everest et al., 2006b; Stone \& Ballantyne, 2006).

\section{Conclusions}

Geomorphological mapping of the area surrounding The Minch in NW Scotland records the signature of a large palaeo-ice stream sourced in the mountains of the NW Highlands, the Isle of Skye and the Isle of Lewis. Onshore mapping, based on new NEXTMap surface models, aerial photographs and field surveys, is combined with sidescan-sonar and multibeam swathsurvey data from $\sim 100 \mathrm{~m}$ water depth offshore. This has led to refinement of Stoker \& Bradwell's (2005) reconstruction and allows several new findings to be presented:

- On the coastal fringes of the NW Scottish mainland, Lewis and Skye, elongate streamlined bedforms, with elongation ratios of 4-8:1, delimit the onset zones of a large $\left(\sim 15,000 \mathrm{~km}^{2}\right)$ palaeo-ice stream.

- Highly elongate streamlined bedforms, with elongation ratios $>10: 1$, were generated beneath a fast-flowing zone of the British-Irish ice sheet, last active during the Late Devensian glaciation (MIS 2). At least 9 ice-stream tributaries coalesced to feed a $\sim 40 \mathrm{~km}$-wide, $\sim 200 \mathrm{~km}$-long ice stream in NW Scotland flowing along the topographic depression of The Minch.

- Mega-scale glacial lineations, with elongation ratios up to 70:1, are observed on the seabed in the central zone of the palaeo-ice stream track, demonstrating that fastflowing ice was in contact with the bed. Cross-cutting, MSGL flow sets probably relate to temporal changes in the dominance of palaeo-ice-stream source areas.

- The southern edge of The Minch palaeo-ice stream crossed the northernmost tip of the Outer Hebrides, depositing shelly till on the Butt of Lewis. At its Late Devensian maximum extent, this grounded ice stream flowed towards the Sula Sgeir fan, and may have terminated as a floating ice shelf near the continental slope.

- During the Last Glacial Maximum (MIS 2), The Minch ice stream would have dictated the overall pattern of ice flow in the NW sector of the British ice sheet. 
Fluctuations in ice stream size and vigour may have lowered the ice-sheet surface across the whole area and forced the ice-divide on the Scottish mainland to migrate eastward.

- Basal shear stresses beneath the trunk of the palaeo-ice stream at the time of maximum glaciation, are estimated to be $<20 \mathrm{kPa}$. This value is in accordance with modern ice-stream observations.

- The Minch palaeo-ice stream probably last operated between 22-25 ka BP (LGM) and $\sim 17 \mathrm{ka} \mathrm{BP}$, when ice was near the present-day coastline in NW Scotland. Ice stream collapse may have been in response to eustatic sea level rise c. $19 \mathrm{ka}$ BP, disintegrating around the time of the North Atlantic iceberg-discharge event Heinrich 1 ( 17-18 ka BP).

\section{Acknowledgments}

We are very grateful to Carol Pudsey (BAS) for alerting us to the opportunity of acquiring the swath bathymetry from the RRS James Clark Ross, and to Peter Morris (BAS) for his assistance in the collection of the data. We also thank Chris Clark, Doug Benn, Dave Long and Nick Golledge for helpful comments on the MS. Published with the permission of the Executive Director, British Geological Survey (NERC).

\section{References}

Alley RB. 1993. In search of ice stream sticky spots. Journal of Glaciology 19: 447-454.

Alley RB, Marotske J, Nordhaus WD, Overpeck JT, Peteet DM, Pielke Jr RA, Pierrehumbert TT, Rhines PB, Stocker TF, Talley LD, Wallace JM. 2003. Abrupt climate change. Science 299: 20052010 .

Alley RB, Whillans IM. 1991. Changes in the West Antartic ice sheet. Science 254: 959-963.

Baden-Powell DFW. 1938. On the glacial and interglacial marine beds of north Lewis. Geological Magazine 75: 395-409.

Ballantyne CK. 1990. The Late Quaternary glacial history of the Trotternish Escarpment, Isle of Skye, Scotland, and its implicationsfor ice-sheet reconstruction. Proceedings of the Geologists' Association 101: 171-186.

Ballantyne CK. 1994. Gibbsitic soils on former nunataks: implications for ice sheet reconstruction. Journal of Quaternary Science 9: 73-80.

Ballantyne CK, McCarroll D. 1995. The vertical dimension of Late Devensian glaciation on the mountains of Harris and SE Lewis, Outer Hebrides, Scotland. Journal of Quaternary Science 10: $211-$ 223.

Ballantyne CK, McCarroll D, Nesje A, Dahl SO, Stone JO. 1998. The last ice sheet in northwest Scotland: reconstruction and implications. Quaternary Science Reviews 17: 149-1184. 
Bamber JL, Vaughan DG, Joughin I. 2000. Widespread complex flow in the interior of the Antarctic Ice Sheet. Science 287: 1248-1250.

Bond G, Heinrich H, Broecker WS, Labeyrie L, McManus J, Andrews JT, Huon S, Jantschick R, Clasen S, Simet C, Tedesco K, Klas M, Bonani G, Ivy S. 1992. Evidence for massive discharges of icebergs into the North Atlantic during the last glacial period. Nature 360: 245-249.

Boulton GS. 1979. Processes of glacier erosion on different substrata. Journal of Glaciology 23: 15-38.

Boulton GS, Clark CD. 1990. A highly mobile Laurentide Ice Sheet revealed by satellite images of glacial lineations. Nature 346: 813-817.

Bowen DQ, Phillips FM, McCabe AM, Knutz PC, Sykes GA, 2002. New data for the Last Glacial Maximum in Great Britain and Ireland. Quaternary Science Reviews 21: 89-102.

Bradwell T. 2005. Bedrock megagrooves in Assynt, NW Scotland. Geomorphology 65: 195-204.

Broecker WS. 2003. Does the trigger for abrupt climate change reside in the ocean or the atmosphere? Science 300: 1519-1522.

Clark CD. 1993. Mega-scale glacial lineations and cross-cutting ice-flow landforms. Earth Surface Processes and Landforms 18, 1-29.

Clark CD, Tulacyzk SM, Stokes CR, Canals M. 2003. A groove-ploughing theory for the production of mega-scale glacial lineations and implications for ice stream mechanics. Journal of Glaciology 49 : 240-256.

Clark CD, Evans DJA, Khatwa A, Bradwell T, Jordan CJ, Marsh SH, Mitchell WA, Bateman MD. 2004. Map and GIS database of landforms and features related to the last British Ice Sheet. Boreas 33: 359-375.

Clark PU, McCabe AM, Mix AC, Weaver, AJ. 2004. Rapid rise of sea level 19,000 years ago and its global implications. Science 304: 1141-1144.

Dowdeswell JA, Ó Cofaigh C, Pudsey CJ. 2004. Thickness and extent of the subglacial till layer beneath an Antarctic paleo-ice stream. Geology 32, 13-16.

Evans DJ, Clark CD, Mitchell WA. 2005. The last British Ice sheet: a review of the evidence utilised in the compilation of the glacial map of Britain. Earth Science Reviews 70: 253-312.

Everest JD, Bradwell T, Golledge N. 2006a. Scottish Landform Example 44: Subglacial bedforms of the Tweed palaeo-ice stream. Scottish Geographical Journal 121: 163-173.

Everest JD, Bradwell T, Fogwill CJ, Kubik PW. 2006b. Cosmogenic ${ }^{10}$ Be age constraints from the Wester Ross Readvance Moraine: insights into British Ice Sheet behaviour. Geografiska Annaler 88A: 9-18.

Fabel D, Stroeven AP, Harbor J, Kleman J, Elmore D, Fink D. 2002. Landscape preservation under Fennoscandian ice sheets determined from in situ produced ${ }^{10} \mathrm{Be}$ and ${ }^{26} \mathrm{Al}$. Earth and Planetary Science Letters 201: 397-406.

Flinn D. 1978. The glaciation of the Outer Hebrides. Geological Journal 13: 195-199.

Geikie J. 1873. On the glacial phenomena of the Long Isle or Outer Hebrides. Journal of the Geological Society of London 29: 532-545.

Geological Survey of Great Britain (Scotland), 1923. Assynt Special Sheet. Solid Geology, 1:63,360. Ordnance Survey for Geological Survey of Great Britain. 
Graham DK, Harland R, Gregory DM, Long D, Morton AC. 1990. The biostratigraphy and chronostratigraphy of BGS Borehole 78/4, North Minch. Scottish Journal of Geology 26: 65-75.

Golledge NR, Stoker MS. 2006. A palaeo-ice stream in Eastern Scotland. Boreas 35: 231-243.

Hall AM, Peacock JD, Connell ER. 2003. New data for the last glacial maximum in Great Britain and Ireland: a Scottish perspective on the paper by Bowen et al. (2002). Quaternary Science Reviews 22: 1551-1554.

Heinrich H. 1988. Origin and consequences of cyclic ice rafting in the northeast Atlantic during the past 130,000 years. Quaternary Research 29: 142- 152.

Hindmarsh RCA. 1998. Drumlinisation and drumlin-forming instabilities: viscous till mechanisms. Journal of Glaciology 44: 293-314.

Hooke RL. 2005. Principles of Glacier Mechanics. $2^{\text {nd }}$ Edition. Cambridge.

Jansson KN, Glasser NF. 2005. Palaeoglaciology of the Welsh sector of the British-Irish Ice sheet. Journal of the Geological Society, London 162: 25-37.

Jehu TJ, Craig RM. 1934. Geology of the Outer Hebrides. Part 5 - North Harris and Lewis. Transactions of the Royal Society of Edinburgh 57: 839-874.

Johnstone GS, Mykura W. 1989. British Regional Geology: the Northen Highlands of Scotland, $4^{\text {th }}$ edition, HMSO: London.

Josenhans H. 1997. Glacial sole markings on bedrock and till in Hudson Bay, Canada. In: Davies TA, Bell T, Cooper AK, Josenhans H, Polyak L, Solheim A, Stoker MS, Stravers JA. 1997. Glaciated Continental Margins: An Atlas of Acoustic Images (Chapman \& Hall: London), 46-47.

Kamb B. 1991. Rheological nonlinearity and flow instability in the deforming bed mechanism of ice stream motion. Journal of Geophysical Research 96: 16585-16595.

Kleman J, Stroeven AP. 1997. Preglacial surface remnants and Quaternary glacial regimes in northwestern Sweden. Geomorphology 19: 35-54.

Lapworth C. 1886. The Highland controversy in British geology: its causes, course, and consequence. Nature 8: 558-559.

Lawson TJ. 1986. Loch Lomond Advance glaciers in Assynt, Sutherland, and their paleoclimatic implications. Scottish Journal of Geology 22: 289-298.

Lawson TJ. 1990. Former ice movement in Assynt, Sutherland as shown by the distribution of glacial erratics. Scottish Journal of Geology 26: 25-32.

Ó Cofaigh C, Pudsey CJ, Dowdeswell JA, Morris P. 2002. Evolution of subglacial bedforms along a paleo-ice stream, Antarctic Peninsula continental shelf. Geophysical Research Letters 29, 10.1029/2001GL014488, 41 (1-4).

Ottesen D, Dowdeswell JA, Rise L. 2005. Submarine landforms and the reconstruction of fast-flowing ice streams within a large Quaternary ice sheet: The 2500-km-long Norwegian-Svalbard margin (5780N0. Geological Society of America Bulletin 117, 1033-1050.

Paterson WSB. 1994. The Physics of Glaciers. $3^{\text {rd }}$ Edition. Pergamon: Oxford.

Peach BN, Horne J. 1892. The ice-shed in the North-west Highlands during the Maximum Glaciation. Report of the British Association for the Advancement of Science 1892: 720-721.

Peach BN, Horne J, Gunn W, Clough CT, Hinxman LW. 1907. The Geological Structure of the Northwest Highlands of Scotland. His Majesty's Stationery Office, Glasgow. 
Peacock JD. 1984. Quaternary Geology of the Outer Hebrides. British Geological Survey Reports, no. $16 / 2$.

Peacock JD. 1991. Glacial deposits of the Hebridean region. In Glacial Deposits of Great Britain and Ireland, Ehlers J, Gibbard PL, Rose J (eds). Balkema: Rotterdam; 109-119.

Pudsey CJ, Barker PF, Larter RD. 1994. Ice sheet retreat from the Antarctic Peninsula shelf. Continental Shelf Research 14: 1647-1675.

Read HH, Phemister J, Ross G. 1926. The Geology of Strath Oykell and Lower Loch Shin, Memoir of the Geological Survey of Scotland, HMSO.

Sejrup HP, Larsen E, Haflidason H, Berstad IM, Hjelstuen BO, Jonsdottir HE, King EL, Landvik J, Longva O, Nygård A, Ottesen D, Raunholm S, Rise L, Stalsberg K. 2003. Configuration, history and impact of the Norwegian Channel Ice Stream. Boreas 32, 18-36.

Sissons JB. 1967. The Evolution of Scotland's Scenery. Oliver \& Boyd: Edinburgh.

Sissons JB. 1980. The glaciation of the Outer Hebrides. Scottish Journal of Geology 16: 81-84.

Smith HTU. 1948. Giant glacial grooves in northwest Canada. American Journal of Science 246: 503514.

Stalsberg K, Larsen E, Ottesen D, Sejrup HP. 2003. Middle to Late Weichselian Norwegian Channel Ice Stream deposits and morphology on Jæren, southwestern Norway and the eastern North Sea area. Boreas 32, 149-166.

Stoker MS. 1995. The influence of glacigenic sedimentation on slope-apron development on the continental margin off northwest Britain. In: Scrutton RA, Stoker MS, Shimmield GB, Tudhope AW. (eds), The Tectonics, Sedimentation and Palaeoceanography of the North Atlantic Region. Geological Society, London, Special Publications 90, 159-177.

Stoker MS, Bradwell T. 2005. The Minch palaeo-ice stream, NW Sector of the British-Irish ice sheet. Journal of the Geological Society, London 162: 425-428.

Stoker MS, Hitchen K, Graham CC. 1993. United Kingdom offshore regional report: the geology of the Hebrides and West Shetland shelves and adjacent deep-water areas. (London: HMSO for the British Geological Survey).

Stokes CR, Clark CD. 1999. Geomorphological criteria for identifying Pleistocene ice streams. Annals of Glaciology 28: 67-74.

Stokes CR, Clark CD. 2001a. Palaeo-ice streams. Quaternary Science Reviews 13: 1436-1458.

Stokes CR, Clark CD. 2001b. Ice stream shear-margin moraines. Earth Surface Processes and Landform 27: 547-558.

Stone JO, Ballantyne CK. 2006. Dimensions and deglacial chronology of the Outer Hebrides Ice Cap, northwest Scotland: implications of cosmic ray exposure dating. Journal of Quaternary Science 21: $75-84$.

Sutherland DG. 1984. The Quaternary deposits and landforms of Scotland and the neighbouring shelves: a review. Quaternary Science Reviews 3: 157-254.

Truffer M, Echelmeyer KA. 2003. Of isbrae and Ice streams. Annals of Glaciology 36: 66-72

Vaughan DG, Corr H, Ferraccioli F, Frearson N, O'Hare A, Mach D, Holt JW, Blankenship DD, Morse DL, Young DA. 2006. New boundary conditions for the West Antarctic ice sheet: subglacial 
topography beneath Pine Island Glacier, Geophysical Research Letters 33: L09501, doi:10.1029/2005GL025588.

von Weymarn JA. 1974. Coastline development in Lewis and Harris, Outer Hebrides, with particular reference to the effects of glaciation. $\mathrm{PhD}$ thesis, University of Aberdeen.

von Weymarn JA. 1979. A new concept of glaciation in Lewis and Harris. Proceedings of the Royal Society of Edinburgh 77B: 97-105. 


\section{Figure captions:}

Figure 1: Location map of the study area in NW Scotland showing all places referred to in the text. Previously proposed British ice-sheet limits are also shown: 1 - Sutherland (1984); 2 - Bowen et al., (2002); 3 - Hall et al., (2003).

Figure 2: LANDSAT TM image of NW Scotland showing location of areas described in the text. A-L: Sub-samples from NEXTMap digital surface model (illumination from the NW) showing areas of glacially streamlined terrain. White arrows indicate dominant direction of ice sheet flow. Note the varying scales; all figures orientated with $\mathrm{N}$ to the top. A - Broad Bay, Lewis; B - W of Stornoway, Lewis; C - Loch Erisort, Lewis; D - Loch Snizort, Skye; E - Loch Laxford, Sutherland; F - Manish Point, Raasay; G - Isle of Ewe, Wester Ross; H - upper Glencoul, Assynt; J - Cam Loch and Elphin, Assynt; K - Rhidorroch, Wester Ross; L - Applecross, Wester Ross. M - Area of multibeam swath survey of seabed, central zone of The Minch.

Figure 3: Mega-scale glacial lineations preserved on the sea floor of The Minch. (i) Multibeam swath bathymetry (illumination from the NE) and (ii) interpreted line drawing of seabed from area $\mathrm{M}$ (on Figure 2), showing two main sets of lineation - a N-S set cut by a NNW-SSE set, the trends of which are indicated on (v) the rose diagram; (iii) and (iv) show sidescan-sonar images from areas $M_{1}$ and $M_{2}$, respectively (along BGS seismic track 85/04-5), with the dark linear elements representing ridges and the pale areas being sand-filled grooves. All profiles were collected in about $100 \mathrm{~m}$ of water depth. (vi) Location map of areas $\mathrm{M}_{1}$ and $\mathrm{M}_{2}$ and BGS seismic track 85/04-5.

Figure 4: Reconstruction of The Minch palaeo-ice stream at maximum extent in the Pleistocene. Grey shaded area shows main trunk of ice stream and tributaries. Black lines are hypothesised palaeo-flow paths; line thickness gives impression of flow strength. Generalised ice-stream onset zone catchments are also shown. White arrows show trend of MSGLs seen in multibeam survey (Fig 3). Dashed line (LGM) shows probable limit of grounded British-Irish ice sheet at last glacial maximum (Late Devensian). Generalised bathymetry with contours at $50 \mathrm{~m}$ vertical intervals. 


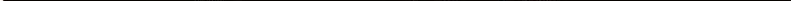



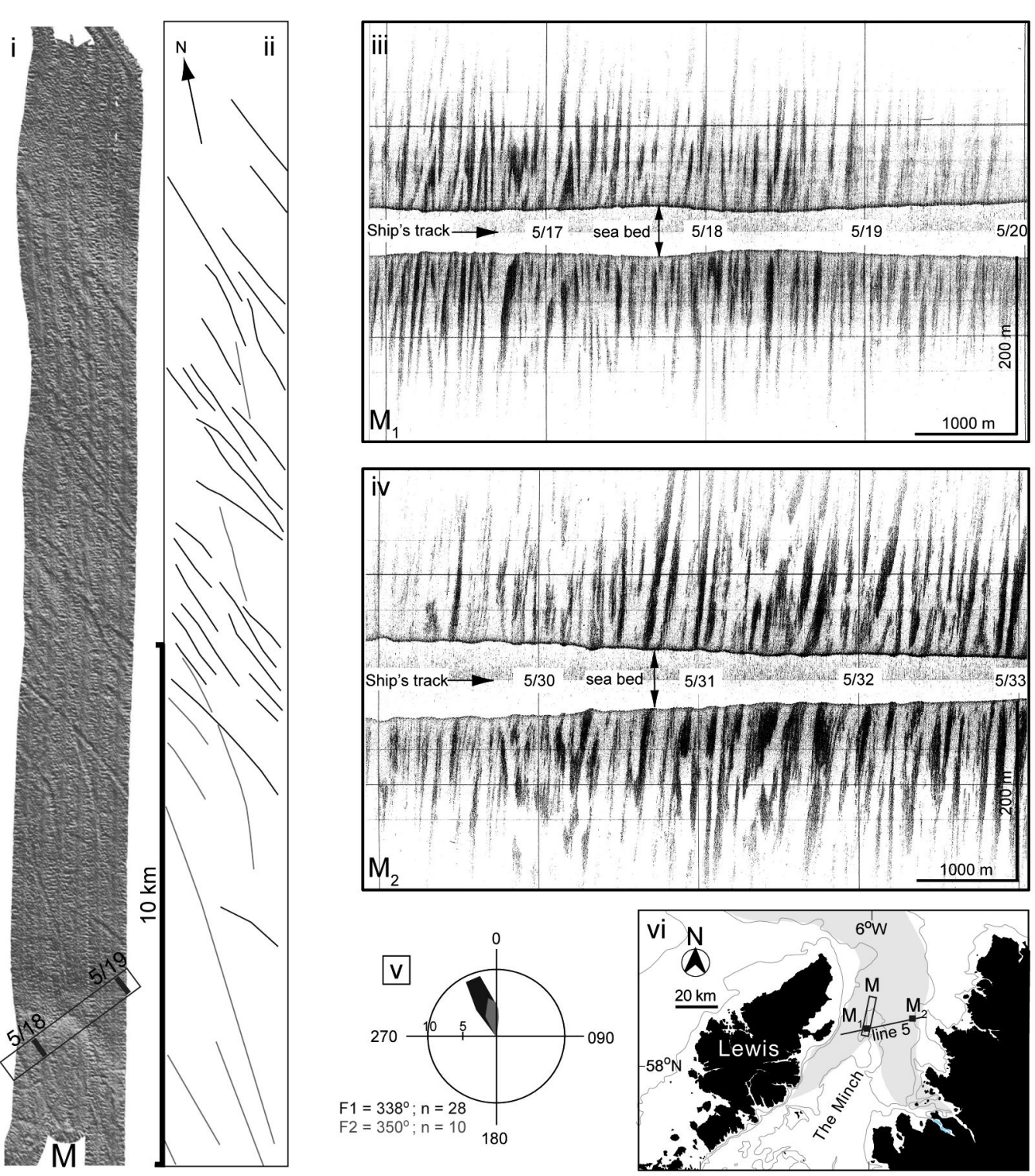
